\title{
Perubahan morfologi sel HeLa setelah paparan ekstrak etanolik Curcuma longa
}

\author{
Suryani Hutomo*, Heni Susilowati* ${ }^{* *}$, Yanti Ivana Suryanto ${ }^{* * *}$, Chandra Kurniawan ${ }^{* * * *}$ \\ *Bagian Mikrobiologi, Fakultas Kedokteran, Universitas Kristen Duta Wacana, Yogyakarta, Indonesia \\ **Departemen Biologi Mulut, Fakultas Kedokteran Gigi, Universitas Gadjah Mada, Yogyakarta, Indonesia \\ ***Bagian Fisiologi, Fakultas Kedokteran, Universitas Kristen Duta Wacana, Yogyakarta, Indonesia \\ ****Prodi Pendidikan Dokter, Fakultas Kedokteran, Universitas Kristen Duta Wacana, Yogyakarta, Indonesia \\ *JI Dr Wahidin 5-25, Yogyakarta, Indonesia; e-mail: suryanihutomo_drg@yahoo.com
}

\begin{abstract}
ABSTRAK
Kunyit (Curcuma longa) merupakan tanaman yang dapat tumbuh di daerah tropis dan sub tropis, serta merupakan tanaman asli Asia Tenggara. Di Indonesia, kunyit menyebar secara merata di seluruh daerah. Kurkumin yang merupakan unsur utama kunyit, merupakan antioksidan yang kuat. Beberapa penelitian juga menunjukkan bahwa kunyit mampu menghambat pertumbuhan beberapa tipe sel kanker. Mekanisme anti-kanker kurkumin adalah dengan menghambat proliferasi sel. Penelitian terdahulu melaporkan bahwa ekstrak Curcuma longa menginduksi apoptosis pada sel HeLa, tetapi mekanisme kematian sel tersebut belum jelas. Tujuan penelitian ini adalah untuk mengkaji pengaruh ekstrak Curcuma longa pada perubahan morfologi sel HeLa, dimana perubahan morfologi merupakan parameter kerusakan sel. Sel HeLa (5x10 $\mathrm{sel} /$ well) dikultur dalam RPMI 1640 semalam sebelum stimulasi. Ekstrak etanol kunyit $(50 \mu \mathrm{g} / \mathrm{ml}, 100 \mu \mathrm{g} /$ $\mathrm{ml}, 150 \mu \mathrm{g} / \mathrm{ml}$ ) ditambahkan pada kultur HeLa dan diinkubasi selama 24 jam dalam medium tanpa antibiotik. Analisis morfologi sel HeLa dilakukan dengan menggunakan mikroskop fase kontras setelah pewarnaan haematoksilen eosin. Doksorubisin $(0,5625 \mu \mathrm{g} / \mathrm{ml})$ digunakan sebagai kontrol positif induksi apoptosis. Hasil penelitian menunjukkan bahwa ekstrak Curcuma longa menyebabkan perubahan morfologi sel yang ditandai dengan semakin mengecilnya ukuran sel, hilangnya prosesus sitoplasmik sehingga sel berbentuk bulat, serta hilang kontak dengan sel lain yang merupakan ciri apoptosis pada sebagian besar sel HeLa. Nukleus tampak berwarna gelap karena peningkatan kapasitas penyerapan zat haematoksilen. Analisa statistik menunjukkan perbedaan yang bermakna antara kelompok kontrol positif dan negatif dengan kelompok stimulasi dalam jumlah sel yang mengalami perubahan morfologi menuju apoptosis. Disimpulkan bahwa ekstrak Curcuma longa mampu menginduksi perubahan morfologi sel HeLa yaitu berupa cell shrinkage.
\end{abstract}

Kata kunci: ekstrak Curcuma longa, perubahan morfologi sel, sel HeLa

\begin{abstract}
Cell morphological changes on HeLa cells after Curcuma longa etanolik extract exposure. Curcuma is mostly found in the areas with tropical and sub-tropical climate, and is one of original plants of Southeast Asia. In Indonesia, curcuma can be found in almost all regions and areas. Curcumin, which is curcuma's main constituent, is a potent anti oxidant. Previous studies reported that curcuma longa extract may decrease the growth of cancer cells by interfering with cell proliferation, and by causing the cell apoptosis; however, the mechanism of apoptosis remains unclear. The purpose of this study was to investigate the effect of Curcuma longa extract on the morphological change of HeLa cells, indicating the cell damage. HeLa cells $\left(5 \times 10^{4}\right.$ cells/well) were cultured in complete RPMI 1640 overnight before stimulation. Etanol extract of Curcuma longa (50 g/ml, $100 \mathrm{~g} / \mathrm{ml}, 150 \mathrm{~g} / \mathrm{ml})$ were added to the culture of HeLa cells and were incubated for 24 hours in antibiotic-free of culture medium. HeLa cells morphological analysis was performed under phase contrast microscope after haematoxilent eosin staining. Docsorubisin $(0,5625 \mathrm{mg} / \mathrm{ml})$ was used as positive control in this study. The results demonstrated that Curcuma longa extract caused cell morphological changes on HeLa cells indicated by cell shrinkage, lost contact with neighboring cells as the alteration of apoptotic cell death in most of cell population. The nuclei were dark as a result of their capability to absorb haematoxylene dye. Statistical analysis showed a significant difference between controls and treatment groups. It was then concluded that Curcuma longa extract induced cell damage on HeLa cells in a way of cell shrinkage.
\end{abstract}

Keywords: Curcuma longa extract, cell morphological change, HeLa cells

\section{PENDAHULUAN}

Kunyit (Curcuma longa) merupakan tanaman yang dapat tumbuh di daerah tropis dan sub tropis, serta merupakan tanaman asli Asia Tenggara. Di India dan Asia Tenggara, rimpang kunyit biasa digunakan sebagai bumbu makanan dan pewarna makanan. Selain itu, kunyit juga menjadi tanaman obat, yang secara tradisional biasa digunakan untuk penyembuhan luka. ${ }^{1}$

Warna kuning kunyit berasal dari yang pigmen polifenol yang larut dalam lemak, yang dikenal dengan nama kurkuminoid. Kurkuminoid menyusun 
sekitar 2-9\% dari kandungan kunyit. Beberapa kandungan kurkuminoid yang bisa ditemukan pada kunyit adalah kurkumin, demethoxykurkumin dan bisdemethoxykurkumin. Kurkumin merupakan unsur yang paling aktif dan yang paling banyak jumlahnya dibandingkan dengan unsur-unsur kurkuminoid lainnya. ${ }^{1}$

Kurkumin [(1E,6E) - 1,7-bis (4-hydroxy-3methixyphenyl) hepta-1, 6-diene-3,5 dione] merupakan pigmen kuning utama yang dihasilkan dari ekstrak kunyit, yang diambil dari rhizoma tanaman kunyit (Curcuma longa). Kurkumin memiliki aksi sebagai antioksidan, antiviral dan antifungal, aksi anti-inflamasi melalui penghambatan beberapa molekul penting yang berperan dalam inflamasi. Efek anti-inflamasi kunyit merupakan kombinasi dari 3 mekanisme, yaitu: pertama, kunyit menurunkan produksi histamin (zat yang menginduksi inflamasi); kedua, kunyit meningkatkan produksi dan memperpanjang daya kerja cortisol yang dihasilkan oleh kelenjar adrenal yang memiliki efek anti-inflamasi; ketiga, kunyit meningkatkan sirkulasi darah, sehingga mampu mengeluarkan toksin-toksin (celular waste dan inflamatory compound) yang sering terperangkap di dalam sendi-sendi kecil. ${ }^{2}$

Beberapa penelitian melaporkan bahwa kurkumin mampu menghambat pertumbuhan beberapa tipe sel kanker. Kurkumin menekan pertumbuhan sel pada kanker kulit, kanker payudara, kanker paru, kanker hati, kanker esofagus, kanker usus, dan kanker kolon dengan menghambat proliferasi sel. ${ }^{3}$ Mekanisme bagaimana kurkumin bisa menimbulkan efek antikanker sangat komprehensif dan bervariasi, melalui berbagai target regulasi proses pertumbuhan sel dan apoptosis. Mekanisme kurkumin menginduksi apoptosis sangat bervariasi, dan diduga melalui penghambatan beberapa cellsignaling pathway. Target-targetnya antara lain transcription factor, oncogens, dan signaling protein. Kurkumin berperan dalam kontrol siklus sel dan stimulasi apoptosis melalui regulasi p16 dan p53. ${ }^{4}$

Penelitian terdahulu melaporkan bahwa kurkumin menyebabkan kematian sel sebanyak separuh dari jumlah sel yang diinduksinya dengan dosis $184,5 \mu \mathrm{g} / \mathrm{ml}$. Dalam penelitian tersebut juga diketahui bahwa kematian sel sebagian berupa apoptosis, meskipun mekanismenya belum jelas. ${ }^{5}$ Tujuan penelitian ini adalah untuk mengkaji pengaruh ekstrak etanolik Curcuma longa terhadap perubahan morfologi sel HeLa. Penelitian ini telah mendapatkan persetujuan etik dari Komisi Etik Fakultas Kedokteran Universitas Kristen Duta Wacana.

\section{METODE PENELITIAN}

1. Ekstraksi Curcuma longa

Kunyit didapatkan dari daerah Bantul, Yogyakarta. Ekstraksi dilakukan dengan metode maserasi. Metode ini dilakukan dengan cara serbuk kunyit (simplisia) yang didapatkan dari rimpang kunyit usia 9 bulan, dimasukkan ke dalam wadah, setelah itu ditambahkan pelarut etanol dengan perbandingan $10: 1$. Simplisia direndam selama 24 jam dengan melakukan pengadukan secara berkala, setelah itu dilakukan penampungan filtrat. Ampas yang didapatkan dari penyaringan kemudian direndam kembali dengan menggunakan etanol $96 \%$. Prosedur ini dilakukan sebanyak 3 kali. Setelah filtrat didapatkan maka dilakukanlah evaporasi dengan menggunakan evaporator hingga dihasilkan ekstrak semi padat etanol rimpang kunyit. Ekstrak kemudian keringkan dalam oven bersuhu $40^{\circ} \mathrm{C}$.

\section{Kultur sel HeLa}

Sel HeLa ditumbuhkan dalam medium RPMI 1640 (Sigma-Aldrich, St Louis, MO, USA) yang disuplementasi dengan 10\% FBS, $100 \mathrm{IU} /$ $\mathrm{ml}$ penisilin, $10 \mu \mathrm{g} / \mathrm{ml}$ streptomisin dalam suhu $37^{\circ} \mathrm{C}$ dengan kadar $\mathrm{CO} 25 \%$. Flask yang berisi sel diinkubasi untuk mendapatkan sejumlah sel yang dibutuhkan (konfluen). Sel HeLa dipanen dengan cara menambahkan $1-2 \mathrm{ml}$ tripsin $0,25 \%$ ke dalam flask dan ditunggu beberapa saat. Sel HeLa kemudian dipindahkan ke conical tube dan ditambahkan medium RPMI hingga volume 10 $\mathrm{ml}$ kemudian disentrifuge selama 5 menit dengan kecepatan $2000 \mathrm{rpm}$.

Supernatan kemudian dibuang, pelet diresuspensi dalam $1 \mathrm{ml}$ medium dan dihitung jumlahnya menggunakan bilik hitung. Suspensi sel dipindahkan pada 24 well-plate yang sudah diberi coverslip, ditambahkan sejumlah medium hingga 
memperoleh konsentrasi sel sebesar $5 \times 10^{4} \mathrm{sel} / 100$ $\mu \mathrm{l}$ dan siap digunakan.

\section{Analisis perubahan morfologi sel HeLa}

Sel HeLa dikultur pada 24 well-plate yang diberi coverslip pada tingkat kepadatan $5 \times 10^{4}$ sel/well. Ekstrak curcumin dilarutkan dengan dimethylsulfoxide (DMSO) dalam konsentrasi awal 1 $\mathrm{mg} / \mathrm{ml}$, selanjutnya dilakukan aliquot dan disimpan pada suhu- $20^{\circ} \mathrm{C}$. Larutan curcumin dalam DMSO diencerkan dalam RPMI tanpa antibiotik hingga konsentrasi final $50 \mu \mathrm{g} / \mathrm{ml}, 100 \mu \mathrm{g} / \mathrm{ml}$ dan $150 \mu \mathrm{g} /$ $\mathrm{ml}$. Setelah semalam kultur, sel dipapar dengan curcumin pada konsentrasi $50 \mu \mathrm{g} / \mathrm{ml}, 100 \mu \mathrm{g} / \mathrm{ml}$ dan $150 \mu \mathrm{g} / \mathrm{ml}$ selama 24 jam. Sebagai kontrol negatif, sel HeLa dikultur dalam RPMI tanpa curcumin, sedangkan sebagai kontrol positif, sel HeLa dikultur dalam RPMI dan dipapar dengan doxorubisin dengan konsentrasi $0,5625 \mu \mathrm{g} / \mathrm{ml}$. Coverslip yang telah dilekati sel Hela kemudian ditempatkan pada glass slide dan dilakukan pengecatan hematoksilen eosin (HE). Pengamatan perubahan morfologi sel HeLa setelah paparan curcumin dilakukan menggunakan mikroskop fasekontras untuk mengidentifikasi dan menghitung jumlah sel yang mengalami perubahan morfologi per 10 lapangan pandang.

\section{ANALISIS STATISTIK}

Hasil penghitungan jumlah sel HeLa yang mengalami perubahan morfologi dikuantifikasi dalam persen yang merupakan data representatif dari 3 kali eksperimen. Tes normalitas dan homogeneitas dilakukan menggunakan tes ShapiroWilk dan Levene. Hasil analisa menunjukkan bahwa data terdistribusi normal, tetapi tidak homogeny dengan signifikansi $p<0,05$. Persentase sel yang mengalami perubahan morfologi dianalisa menggunakan tes Kruskal Wallis. Post Hoc Multiple Comparison dilakukan untuk menganalisa mean differences diantara grup. Signifikansi statistik didapatkan dengan harga $p<0,05$.

\section{HASIL PENELITIAN}

Hasil penelitian menunjukkan bahwa sel HeLa yang normal berbentuk poligonal atau bulat dengan sitoplasma yang luas. Beberapa sel memiliki proscessus (Gambar A). Morfologi sel HeLa berubah setelah sel dipapar curcumin. Tampak sel yang mengalami pengkerutan (shrinkage) dan hilang kontak dengan sel tetangga. Sebagian proscessus sitoplasma menghilang, menyebabkan sel tampak berukuran lebih kecil. Rasio sitoplasma dan nukleus berkurang (Gambar C, D, E). Kerusakan seluler ditandai dengan perubahan morfologi sel menjadi bulat dengan kemampuan penyerapan intensitas penyerapan warna hemaktoksilen yang lebih tinggi, sehingga sel berwarna lebih gelap.

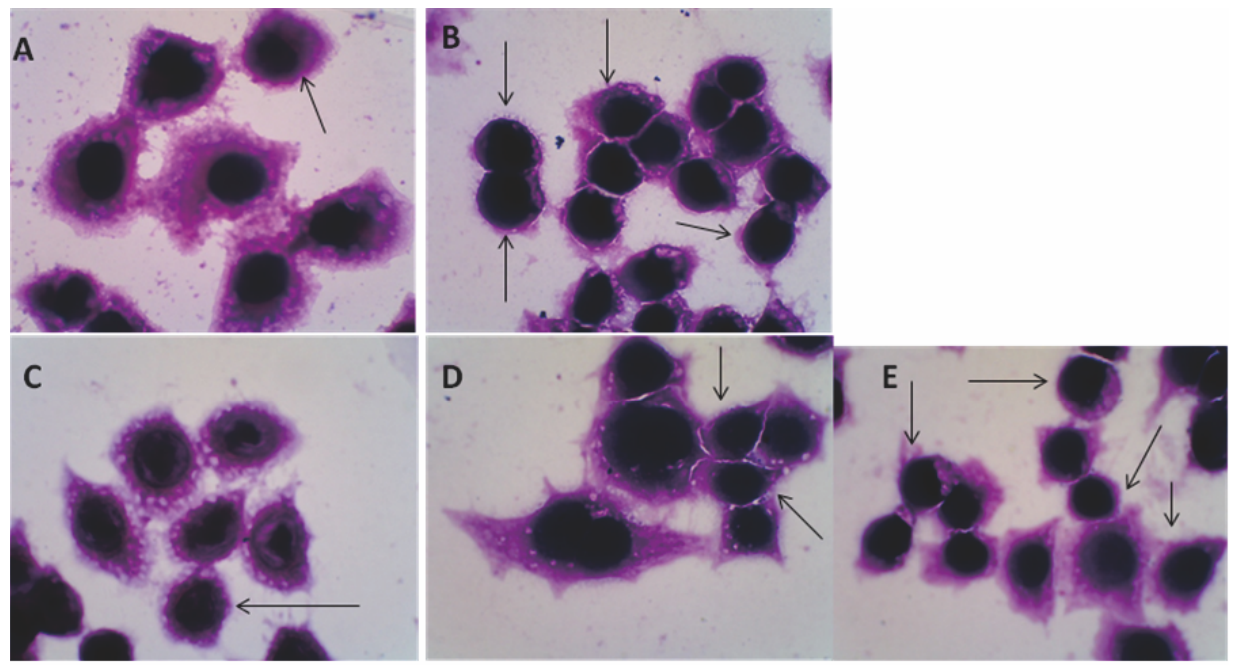

Gambar 1. Sel HeLa tanpa paparan kurkumin tampak mempunyai proscesus dan sitoplasma yang luas (A).Perubahan morfologi terjadi pada sel HeLa yang dipapar kurkumin dengan konsentrasi $50 \mu \mathrm{g} /$ $\mathrm{ml}(\mathrm{C}), 100 \mu \mathrm{g} / \mathrm{ml}(\mathrm{D}), 150 \mu \mathrm{g} / \mathrm{ml}(\mathrm{E})$, berupa cellshrinkage, hilang kontak dengan sel-sel di sekitarnya. Pada kontrol positif sebagian besar sel mengalami shrinkage dan sitoplasma hampir hilang (B). 
Tabel 1. Rerata dan deviasi standar persentasi sel HeLa setelah dipapar kurkumin

\begin{tabular}{llllll}
\hline Grup & Kontrol - & $50 \mu \mathrm{g} / \mathrm{ml}$ & $100 \mu \mathrm{g} / \mathrm{ml}$ & $150 \mu \mathrm{g} / \mathrm{ml}$ & Kontrol + \\
\hline $\begin{array}{l}\text { Persentase sel } \\
\text { yang mengalami }\end{array}$ & $1,33 \pm 0,2214$ & $22,99 \pm 0,3143$ & $31,71 \pm 0,3985$ & $42,12 \pm 0,3765$ & $81,15 \pm 0,6737$ \\
$\begin{array}{l}\text { perubahan mor- } \\
\text { fologi }\end{array}$ & & & & \\
\hline
\end{tabular}

Data representative dari 3 kali eksperimen

Jumlah sel yang mengalami perubahan morfologi meningkat seiring dengan bertambah besarnya konsentrasi curcumin seperti tercantum pada Tabel 1. Shapiro-Wilk test digunakan untuk menganalisa normalitas data. Harga $p$ untuk kelompok kontrol, stimulasi ekstrak $50 \mu \mathrm{g} / \mathrm{ml}$, $100 \mu \mathrm{g} / \mathrm{ml}, 150 \mu \mathrm{g} / \mathrm{ml}$ kontrol positif berturut-turut 0,$648 ; 0,281 ; 0,664 ; 0,274$ dan 0,352 . Nilai $p$ mengindikasikan bahwa data terdistribusi normal. Selanjutnya Levene test digunakan untuk menguji homogenitas data. Nilai $p$ untuk semua data lebih kecil dari $\alpha(0,05)$ yang artinya data tidak homogen.

Guna menguji pengaruh konsentrasi kurkumin terhadap persentase sel yang mengalami perubahan morfologi dilakukan tes Kruskal Wallis dan didapatkan nilai $\mathrm{p} 0,00$ yang artinya terdapat perbedaan yang bermakna pada konsentrasi ekstrak kurkumin terhadap persentase sel yang mengalami perubahan morfologi (Tabel 2). Persentase tertinggi perubahan morfologi sel HeLa terdapat pada kelompok yang distimulasi dengan ekstrak konsentrasi $150 \mu \mathrm{g} / \mathrm{ml}$.

Tabel 2. Tes Kruskal Wallis

\begin{tabular}{|l|r|}
\hline & persentase sel apoptosis \\
\hline Chi-Square & 47,093 \\
df & 4 \\
Asymp. Sig. &, 000 \\
\hline
\end{tabular}

\section{PEMBAHASAN}

Hasil penelitian ini menunjukkan bahwa ekstrak etanolik Curcuma longa dapat menyebabkan kerusakan sel yang mengarah pada kematian pada sel HeLa. Pengerutan sel (shrinkage) mulai tampak pada paparan ekstrak dengan konsentrasi $50 \mu \mathrm{g} /$ $\mathrm{ml}$ dan prosentase tersebut semakin meningkat pada konsentrasi $100 \mu \mathrm{g} / \mathrm{ml}$ dan $150 \mu \mathrm{g} / \mathrm{ml}$. Ukuran sel tampak lebih kecil dan hilang kontak dengan sel-sel di sekitarnya. Sel mengalami peningkatan kemampuan penyerapan warna hemaktoksilen yang lebih tinggi, sehingga berwarna lebih gelap. Sel-sel pada kelompok yang dipapar dengan ekstrak konsentrasi $150 \mu \mathrm{g} / \mathrm{ml}$ menunjukkan bahwa 42,12\% diantaranya mengalami perubahan morfologi.

Pada proses awal apoptosis, sel mengalami dehidrasi. Hilangnya cairan intraseluler menyebabkan kondensasi sitopasma yang berakibat pengecilan ukuran sel. Bentuk sel juga berubah, sel menjadi lebih pipih. ${ }^{6}$ Ciri khusus dari apoptosis adalah adanya piknosis yang disebabkan oleh kondensasi kromatin. Proses awal ini, shrinkage dan piknosis dapat diamati dengan mikroskop fase kontras. Fenomena-fenomena ini didapatkan pada hasil penelitian, sehingga dapat disimpulkan bahwa kurkumin menyebabkan kerusakan sel yang mengarah pada apoptosis pada sebagian besar sel. ${ }^{7}$

Apoptosis dapat terjadi pada keadaan fisiologis maupun patologis. Pada keadaan fisiologis, apoptosis terjadi untuk menjaga homeostasis jaringan pada hewan dewasa, pada sistem imun dimana sel $B$ dan sel T mati selama proses maturasi serta untuk menghilangkan sel yang terinfeksi maupun sel yang rusa. ${ }^{8}$ Pada penelitian ini juga didapatkan hasil sama, dimana pada kelompok kontrol negatif didapatkan sel yang mengalami perubahan bentuk mengarah pada apoptosis sebanyak $1,33 \%$. Apoptosis yang patologis didapatkan pada penyakit Alzheimers, Parkinson dan stroke. ${ }^{7}$

Wilken ${ }^{4}$ melaporkan bahwa kurkumin memiliki efek antikanker melalui mekanisme sebagai berikut. Pertama kurkumin menghambat aktivasi NF-ḱB melalui inihibisi akitivitas lḱB sehingga mengakibatkan supresi gen yang berperan dalam tumorgenesis seperti TNF, COX-2, cyclin D1, c-myc, MMP-9 dan interleukin. Kedua, kurkumin berperan 
dalam pengontrolan siklus sel dan stimulasi apoptosis melalui regulasi p16 dan p53, dan ketiga kurkumin merupakan modulator autophagy dan mempunyai efek penghambatan terhadap angiogenesis tumor dan menghambat metastasis melalui supresi berbagai growth factor termasuk VEGF, COX-2, MMPs and ICAMs. Meskipun demikian tidak semua penelitian menunjukkan kurkumin mampu menginduksi apoptosis pada sel kanker. Diantaranya adalah penelitian yang dilakukan oleh Mooset al. ${ }^{8}$ yang menunjukkan bahwa kurkumin menghambat apoptosis yang diinduksi oleh p53 (tumor supression protein) pada kultur sel kanker kolon. Kurkumin juga menginhibisi apoptosis pada kultur sel kanker payudara dengan konsentrasi 1-10 $\mu \mathrm{M} /$ liter. $^{9}$ Berdasarkan hal-hal tersebut maka penting untuk dilakukan penelitian lebih lanjut tentang mekanisme molekuler kurkumin dalam menginduksi apoptosispada sel HeLa yang merupakan model sel kanker epitelium.

\section{KESIMPULAN}

Kurkumin menyebabkan kerusakan sel pada sebagian besar sel HeLa berupa shrinkage yang merupakan ciri apoptosis.

\section{UCAPAN TERIMAKASIH}

Ucapan terimakasih disampaikan kepada Laboratorium Pengujian dan Penelitian Terpadu (LPPT) Universitas Gadjah Mada Yogyakarta.

\section{DAFTAR PUSTAKA}

1. Nayak PL, Palve YHP. Curcumin: a wonder anticancer drug. Int J Pharm Biomed. 2012; 3(2): $60-69$.
2. Akram M, Uddin $S$, Ahmed $A$, Usmanghani K, Hannan A, Mohiuddin E, Asif M. Curcuma longa and curcumin. J Biol. - Plant Biol, Bucharest. 2010; 55(2): $65-70$.

3. Moos PJ, Edes K, Mullally JE, Fitzpatrick FA. Curcumin impairs tumor suppressor p53 function in colon cancer cells. Carcinogenesis. 2004; 25(9): 1611 - 1617.

4. Wilken R, Veena MS, Wang MB, Srivatsan ES. Curcumin: A review of anti-cancer properties and therapeutic activity in head and neck squamous cell carcinoma. Molecular cancer.2011 (diakses dari: http://www. molecular-cancer.com/content/10/1/12)

5. Kurniawan C. Uji sitotoksisitas ekstrak curcuma longa terhadap sel kanker serviks (HeLa), Studi in vitro. Skripsi. 2013.

6. Darzynkiewicz Z, Juan G, Li X, Gorczyca W, Murakami T, Traganos F. Cytometry in cell necrobiology: analysis of apoptosis and accidental cell death (necrosis). Cytometry. 1997; 27(1): 1 - 20.

7. Elmore S. Apoptosis: A review of programmed cell death. Toxicol Pathol. 2007; 35(4): 495 516.

8. Porth CM, Matfin G. Pathophysiology: concepts of altered health states. $8^{\text {th }}$ ed. Lippincott Williams \& Wilkins. Philadelphia: USA; 2009. 94 - 111.

9. Moos PJ, Edes K, Mullally JE, Fitzpatrick FA. Curcumin impairs tumor suppressor p53 function in colon cancer cells. Carcinogenesis. 2004; 25(9): 1611 - 1617. 